\title{
Scientific Trials-In the Laboratories, Not the Courts
}

\section{Citation}

Bagley, Nicolas, Aaron E. Carroll, and Pieter A. Cohen. 2018. "Scientific Trials-In the Laboratories, Not the Courts." JAMA Internal Medicine 178 (1) (January 1): 7. doi:10.1001/ jamainternmed.2017.5730.

\section{Published Version}

10.1001/jamainternmed.2017.5730

\section{Permanent link}

http://nrs.harvard.edu/urn-3:HUL.InstRepos:34902783

\section{Terms of Use}

This article was downloaded from Harvard University's DASH repository, and is made available under the terms and conditions applicable to Other Posted Material, as set forth at http:// nrs.harvard.edu/urn-3:HUL.InstRepos:dash.current.terms-of-use\#LAA

\section{Share Your Story}

The Harvard community has made this article openly available.

Please share how this access benefits you. Submit a story.

Accessibility 


\section{Scientific Trials-In the Laboratories, Not the Courts}

Nicolas Bagley, JD

University of Michigan Law School, Ann Arbor, Michigan.

\section{Aaron E. Carroll, MD,}

MS

Indiana University School of Medicine Indianapolis, Indiana.

\section{Pieter A. Cohen, MD}

Cambridge Health

Alliance, Harvard

Medical School

Somerville,

Massachusetts.

\section{Corresponding}

Author: Pieter A.

Cohen, MD, Cambridge Health Alliance,

Harvard Medical

School, 236 Highland

Ave, Somerville, MA

02143 (pcohen

@challiance.org).
In 2015, one of us published a peer-reviewed study, together with colleagues at the University of California, San Francisco, replicating prior research from the US Food and Drug Administration (FDA) detecting a designer stimulant, $\beta$-methylphenylethylamine, in sports, weight loss, and "cognitive function" supplements sold in the United States. ${ }^{1,2}$ The confirmatory study prompted the FDA to take enforcement action against companies selling the stimulant as a dietary ingredient. ${ }^{3}$

One of the companies that received an FDA warning letter sued the study's authors for $\$ 200$ million in damages for libel, claiming, without supporting scientific evidence, that multiple statements in the article were false. ${ }^{4}$ Following intrusive discovery and a 7-day jury trial in federal court, a Massachusetts jury rejected the company's claims and entered a verdict in the authors' favor. ${ }^{5}$

The case is just a recent example of using litigation to target scientists. In 2008, the manufacturer of a hip protector sued a Harvard researcher for commercial disparagement over a study published in JAMA demonstrating that the hip protector did not prevent fractures. ${ }^{6}$ In 2012, the chief executive officer of a pharmaceutical company sued a researcher who chaired his data monitoring committee after the researcher published an article in Annals of Internal Medicine explaining how the CEO mischaracterized study results. ${ }^{7}$ (The CEO was later convicted of wire fraud.) And, in 2013, a biomarker company sued a group of scientists and an academic journal, Clinical Chemistry, for publishing a study suggesting that the company's assay was insufficiently sensitive. $^{8}$

In all of these cases, the research in question was vetted through peer review and published in reputable journals. Aggrieved executives, however, may not use the conventional approaches to challenging research findings: publishing rebuttals, writing letters to the editor, replicating studies, and the like. Instead, whether through discovery or subpoenas, plaintiffs' lawyers may probe scientists' private communications, which they may then try to exploit to suggest that the research was biased, unethical, or vindictive.

When lawsuits target scientists, it does not matter that plaintiffs almost never win. It does not even matter if the case goes to trial. The goal is to intimidate. In the lawsuit over dietary supplements, for example, the head of the company who brought the suit openly admitted that he was "hoping that we were able to silence this guy," ${ }^{5}$ as well as other researchers who might raise questions about the supplement industry. The most frivolous lawsuit can generate substantial legal costs, distract scientists from research, force the indiscriminate disclosure of laboratory notebooks and emails, and create unnecessary stress for colleagues and families.
Just the possibility of litigation casts a shadow. Young researchers may shy away from fields that could make them targets. Universities might quietly discourage work that could embroil them in expensive litigation. Scientists may explicitly avoid lines of inquiry into the safety and value of commercial products-the very research that could make an immediate difference in people's lives.

Lawyers and judges sometimes resist the idea of singling out a category of litigation for special condemnation. They worry in particular about infringing on the right of access to the courts for redress of legitimate grievances. But lawsuits brought to harass researchers raise concerns above and beyond the ordinary case. These concerns are not new. As a federal appeals court noted in 1982, litigation "inevitably tends to check the ardor and fearlessness of scholars, qualities at once so fragile and so indispensable for fruitful academic labor." 9

It is not just scientists who suffer from abusive lawsuits-it is science itself.

That is why it is crucial for judges to quickly dispose of meritless lawsuits filed for the purpose of discouraging research. They have any number of tools to do so. As the Supreme Court has held, courts need not accept vague allegations of conspiracy, bias, or conflicts of interest. ${ }^{10}$ They should respect state-law privileges that protect researchers from lawsuits over scientific speech. When appropriate, any discovery should be carefully circumscribed and overseen. Judges should zealously apply laws, on the books in more than half the states, that allow for the rapid dismissal of strategic lawsuits against public participation (SLAPP). These anti-SLAPP statutes, which typically allow defendants to recover their attorneys' fees, discourage the filing of meritless lawsuits that serve no other purpose than to silence opposing points of view.

Moreover, courts should not allow lawsuits to proceed to trial solely on the basis of warring affidavits over a study's soundness or conclusions. It is easy to find "experts"-typically paid hourly rates-who are willing to present a contrary opinion or second-guess a study, allowing the plaintiff to claim there are "disputed facts" that must be submitted to a full trial. But a researcher can be held legally responsible for making false statements only when he or she is deliberately lying, knows the statement to be false, or is reckless about the truth of what is being said. Such malfeasance is uncommon enough that, absent concrete evidence to the contrary, alleged lapses in scientific judgment should not be taken as evidence of academic fraud.

When there are concerns that errors and mistakes may be evidence of academic fraud, they should be addressed through the regular academic channels. 
Universities should be contacted and asked to investigate, as should journal editors. There are mechanisms for faculty and research review. And should evidence of fraud be unearthed-such as the falsification of data or the knowing misrepresentation of resultscourts could at that point allow legal cases to proceed. In general, however, the courtroom is not the place to resolve scientific disputes.

Finally, courts should do more to discourage abusive lawsuits from being brought in the first place. At a minimum, plaintiffs should bear their opponents' attorneys' fees. Courts can go further, though.
They should also consider sanctioning attorneys who are unethical enough to represent clients whose only goal is to discourage science. Judges can publicly reprimand lawyers, refer them for disciplinary action to the bar, and even impose monetary sanctions. If attorneys recognized that frivolous, antiscience litigation will be dealt with harshly, they might be more likely to turn away clients that aim to silence researchers whose findings they dislike.

The laboratory and the court are both truth-seeking institutions, but they do not mix well. In doing their work, courts should give scientists space to do theirs.

\section{ARTICLE INFORMATION}

Published Online: November 6, 2017 doi:10.1001/jamainternmed.2017.5730

Conflict of Interest Disclosures: None reported.

REFERENCES

1. Cohen PA, Bloszies C, Yee C, Gerona R. An amphetamine isomer whose efficacy and safety in humans has never been studied,

$\beta$-methylphenylethylamine (BMPEA), is found in multiple dietary supplements. Drug Test Anal. 2016 8(3-4):328-333.

2. Pawar RS, Grundel E, Fardin-Kia AR, Rader J. Determination of selected biogenic amines in Acacia rigidula plant materials and dietary supplements using LC-MS/MS methods. J Pharm Biomed Anal. 2014;88:457-466.

3. Correll WA. US Food and Drug Administration. Warning Letter: Hi-Tech Pharmaceuticals, Inc. 4/22/15. https://www.fda.gov/ICECI /EnforcementActions/WarningLetters /ucm444040.htm. Published April 22, 2015. Accessed August 21, 2017

4. Hi-Tech Pharmaceuticals v. Cohen, No. 16-10660 (D. Mass. 2016).

5. Robbins R. A supplement maker tried to silence this Harvard doctor-and put academic freedom on trial. STAT News. https://www.statnews.com/2017 /01/10/supplement-harvard-pieter-cohen/. Published January 10, 2017. Accessed August 30, 2017.
6. HipSaver Inc. v. Kiel, 464 Mass. 517 (Mass. 2013).

7. Harkonen v. Fleming, 880 F.Supp.2d 1071 (N.D. Cal. 2012).

8. Clinical Care Diagnostics Inc. v. American Association for Clinical Chemistry Inc., 2014 WL 634206 (S.D. Cal. 2014)

9. Dow Chemical Co. v. Allen, 672 F.2d 1262, 1276 (7th Cir. 1982) (quoting Sweezy v. New Hampshire, 354 U.S. 234, 262 (1957) (Frankfurter, J., concurring in the judgment).

10. Bell Atlantic Corp. v. Twombly, 550 U.S. 544 (2007); Ashcroft v. Iqbal, 556 U.S. 662 (2009). 